\title{
Nickel silicide contact for silicon solar cells
}

\author{
S BANDOPADHYAY, U GANGOPADHYAY, \\ K MUKHOPADHYAY, H SAHA and A P CHATTERJEE* \\ Department of Electronic and Telecommunication Engineering, Jadavpur University, \\ Calcutta 700032 , India \\ *Central Glass and Ceramic Research Institute, Calcutta 700032, India
}

\begin{abstract}
Electroless nickel metallization on textured front surface is carried out to fabricate large area $(13 \%)$ efficient silicon solar cells. It is establshed through XPS analysis that NiSi is formed at the front grid contact on the texturized surface at relatively low temperature leading to a low value of series resistance of the solar cells.
\end{abstract}

Keywords. Nickel silicide contact; silicon solar cells: nickel metallization.

\section{Introduction}

Metallization of solar cell plays an important role in the fabrication of solar cells both in terms of efficiency and cost (Anderson and Petersen 1980; Grenon et al 1981; Cocorullo et al 1984; Pereyra and Andrade 1984). It is estimated that around $40 \%$ of the total solar cell processing cost is due to the cost of metallization using conventional technique of screen printing and firing of silver and silver aluminium pastes. It is thus essential to bring down the solar cell metallization cost from its present level.

One technique which reduces the cost of metallization contact is nickel deposition by an electroless technique followed by deposition of the solder material ( $\mathrm{Sn}-\mathrm{Pb}$ alloy) for thickening the metal layer. The interest in this method is mainly due to its remarkable economic advantages (Cocorullo et al 1984; Pereyra and Andrade 1984): (i) Metallization is a very simple low-cost process and can be easily automated. (ii) Realization of the front grid and the back contact is simultaneous. (iii) Nickel deposition is selective so that metallization can be achieved without loss of material. (iv) The deposited nickel is solderable.

To the best of our knowledge, no analysis of the nickel-silicon alloy formation at the silicon interface of the solar cells has been reported so far, although it is well known that for making a good and durable contact, nickel in contact with silicon should undergo alloying reactions at relatively low temperatures, resulting in the growth of metallic silicides at the interface (Lee 1969; Tu 1975; Tu et al 1975; Coleman et al 1976; Scott and Stella 1976; Walser and Bene 1976; Coleman et al 1978; Anderson and Petersen 1980; Grenon et al 1981; Lue et al 1981; Sze 1981; Schmid et al 1983; Sopori and Pryor 1983; Cocorullo et al 1984; Pereyra and Andrade 1984; Singh et al 1986; Green and Cambbell 1987; John et al 1987; Rastogi et al 1988). Since the silicides are metallic and the morphology of their interfaces with silicon is quite uniform, they have been used as a contact layer on silicon devices. A silicide silicon interface gives rise to the Schottky barrier over the silicon. If the barrier height is made low or its width extremely narrow, then the silicide-silicon interface can be used as an ohmic contact interface (John et al 1987). These have important applications in semiconductor device technology. Silicide phase can be examined by Auger electron spectroscopy (AES) or by X-ray photoelectron spectroscopy (XPS) or by Rutherford back-scattering (RBS). 
In this paper we use electroless nickel metallization for single-crystal silicon solar cell. Nickel-silicide contacis are made by heat treatment of the cell (Grenon et al 1981; Rastogi et al 1988). The chemical nature of nickel-silicide growth stages is analysed by $X$-ray photoelectron spectroscopy (XPS) (Rastogi et al 1988). In $\$ 2$, we report the fabrication technique of the solar cell and describe the electroless nickel metallization and silicide formation on the solar cells. The measurements of the parameters of the solar cells and XPS analysis are reported in $\$ 3$. The results and conclusion are described in $\$ \$ 4$ and 5 respectively.

\section{Fabrication of solar cell}

As-cut p-type (100) single crystal silicon wafers of $1-5 \mathrm{ohm}$-cm resistivity, $75 \mathrm{~mm}$ diam and $350 \mu$ thickness were polished in hot $\mathrm{NaOH}$ solution for a few minutes. The alkali polished wafers were then cleaned several times in deionized water and then texturized in hot alkali solution for a suitable time so that the average height of the pyramids of the textured surface was not more than $10 \mu \mathrm{m}$ (Lee 1969; Colman et al 1976: Scott and Stella 1976; Sopori and Pryor 1981; Green and Cambbell 1987; Sze 1981). The pyramid height was estimated from SEM (Hitachi S-415A) photographs (figure 1).

Diffusion was carried out at a temperature of $900^{\circ} \mathrm{C}$ using $\mathrm{POCl}_{3}$ liquid diffusion sources. $\mathrm{POCl}_{3}$ bubbler was maintained at $4^{\circ} \mathrm{C}$ and nitrogen bubbled through the $\mathrm{POCl}_{3}$ bubbler while a mixture of oxygen and nitrogen $(1: 10)$ was flown directly through the diffusion furnance tube (Omega Iunior, Tempress, USA, the Netherlands). The sheet resistance of the diffused layer was kept within $20-30 \mathrm{ohm} / \square$. The junction formed at the edge of the diffused wafer was removed by standard CP4 etchant.

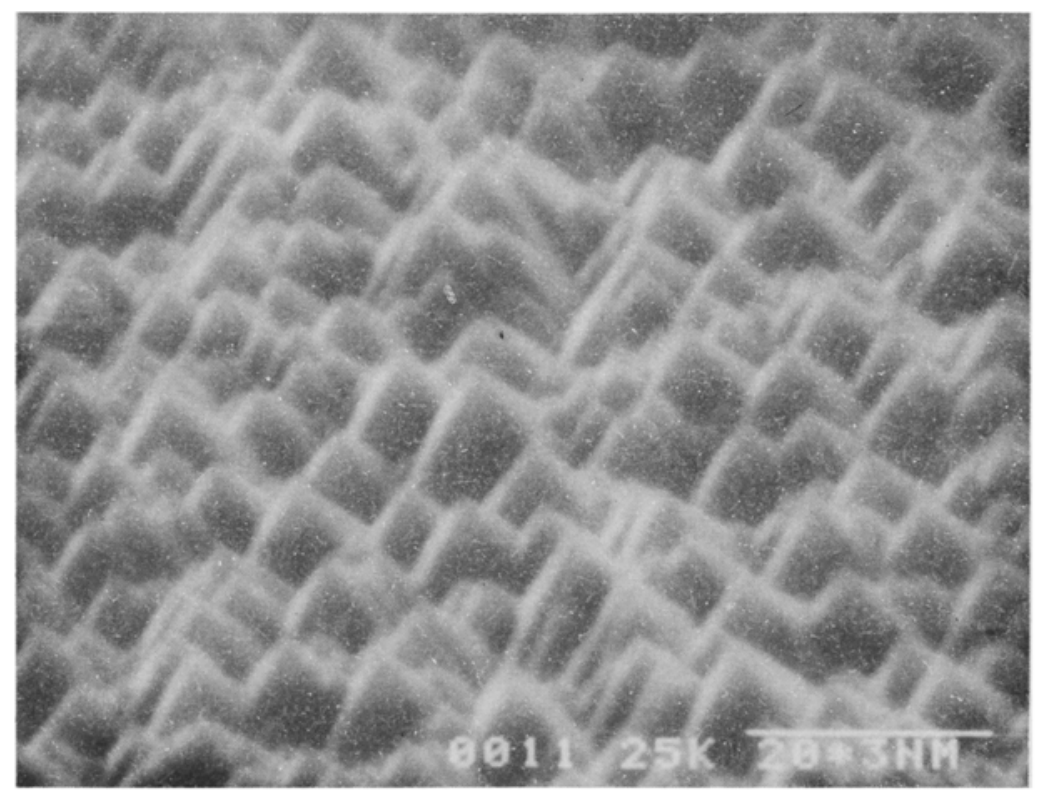

Figure 1. SEM photograph of textured silicon (100) surface. 


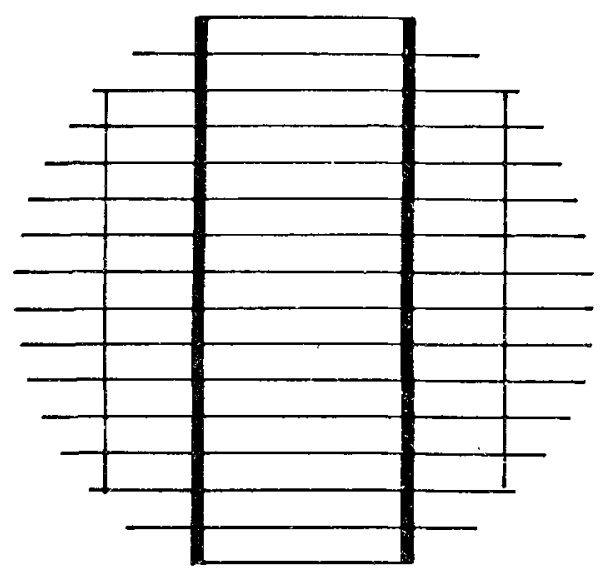

Figure 2. Mask design for front nickel silicide contact grid.

In order to make the $P^{+}$region at the back surface of the cells, an aluminium paste was screen-printed onto the rear surface of the cells. The paste was dried in a hot air oven and then sintered at $800-850^{\circ}$ in an open tube furnace. During sintering a portion of the aluminium melted and alloyed with the silicon. During cooling a thin $p^{+}$layer was produced by liquid phase epitaxial growth of primary silicon from the melt. At the eutectic temperature an aluminium-rich layer of silicon-aluminium eutectic recrystallized over the $p^{+}$layer. The outer portion of the aluminium paste was heavily oxidized. This oxide layer was removed to take any contact from the back surface.

For front contact grid, a normal circular mask with two-tapered busbar and finger lines (width $300 \mu \mathrm{m}$ and separation $4 \mathrm{~mm}$ ) was formed on silk screen (figure 2). The mask had nearly $10 \%$ shading loss.

\subsection{Metallization and silicide formation}

The front grid pattern was formed directly on $n^{+}$layer by silk screen printing with a suitable ink. Aluminium oxide layer on the back surface was removed by a suitable etchant at high temperature before the front grid pattern was formed. The cells were first dipped in $10 \%$ HF for $15 \mathrm{~s}$, cleaned by deionized water and then placed in an electroless nickel bath (Gangopadhyay et al 1987). An excellent adherent Ni plating on the front grids and back surface was obtained for the cells. The cells were cleaned with deionized water, dried and annealed for $5 \mathrm{~min}$ at a temperature of $250-275^{\circ} \mathrm{C}$ in open air for silicide formation. The cells were cooled and dipped into molten solder material at $200^{\circ} \mathrm{C}$. A good thickening of front and back metal layers of the cells was obtained. A flow chart of silicon solar cell fabrication process is given in figure 3 .

\section{Measurements}

The cells fabricated as above were analysed for their current-voltage characteristics and nickel silicide composition. 


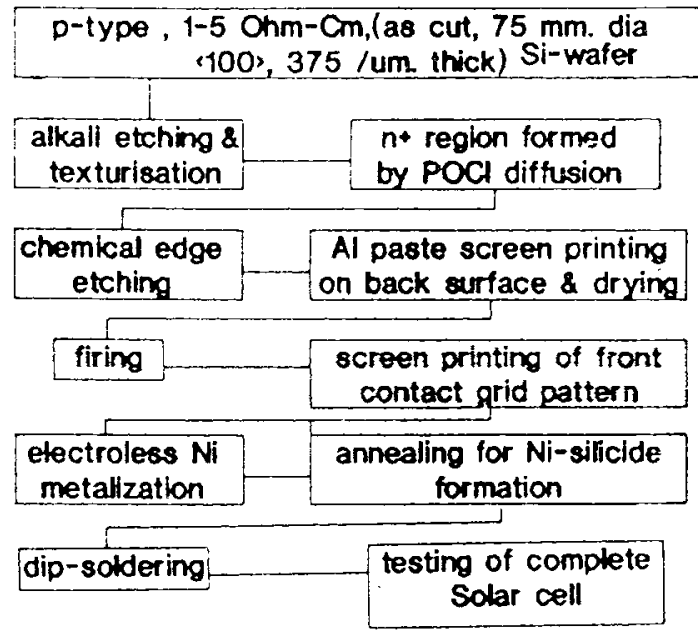

Figure 3. A flow chart of fabrication process of single crystal silicon solar cell.

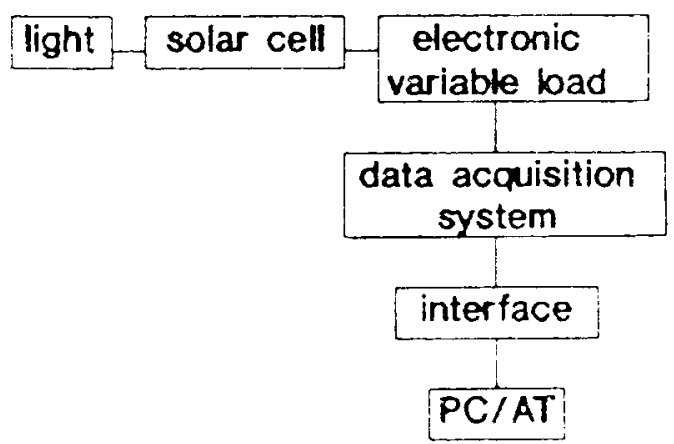

Figure 4. Experimental setup for measuring $V-I$ characteristics of the solar cell.

\subsection{V-I characteristics}

The $V-I$ characteristics of the solar cells was measured using the standard arrangement shown in figure 4. Quartz halogen lamp was used as the source. The variable electronics load drives the cell from open-circuit to short-circuit condition and computerized data acquisition system plots the $V-I$ characteristics of the cell and evaluates the various solar cell parameters (Bhattacharya and Saha 1986). A typical $V-I$ characteristics is shown in figure 5.

\subsection{XPS analysis of nickel silicide}

Nickel silicide was characterized by XPS analysis. XPS studies were carried out using VG MICROLAB MK II system with Al K X-ray source $(h v=1486.6 \mathrm{eV})$ at a base pressure of $\sim 10^{-9} \mathrm{mbar}$ in the analysis chamber. The photoelectron spectra of the nickel silicide layer were recorded after Argon ion $\left(\mathrm{Ar}^{+}\right)$etching at the rate of $\sim 50 \AA / \mathrm{min}$ for $5 \mathrm{~min}$, to remove the surface oxide layer formed during $275-300^{\circ} \mathrm{C}$ 


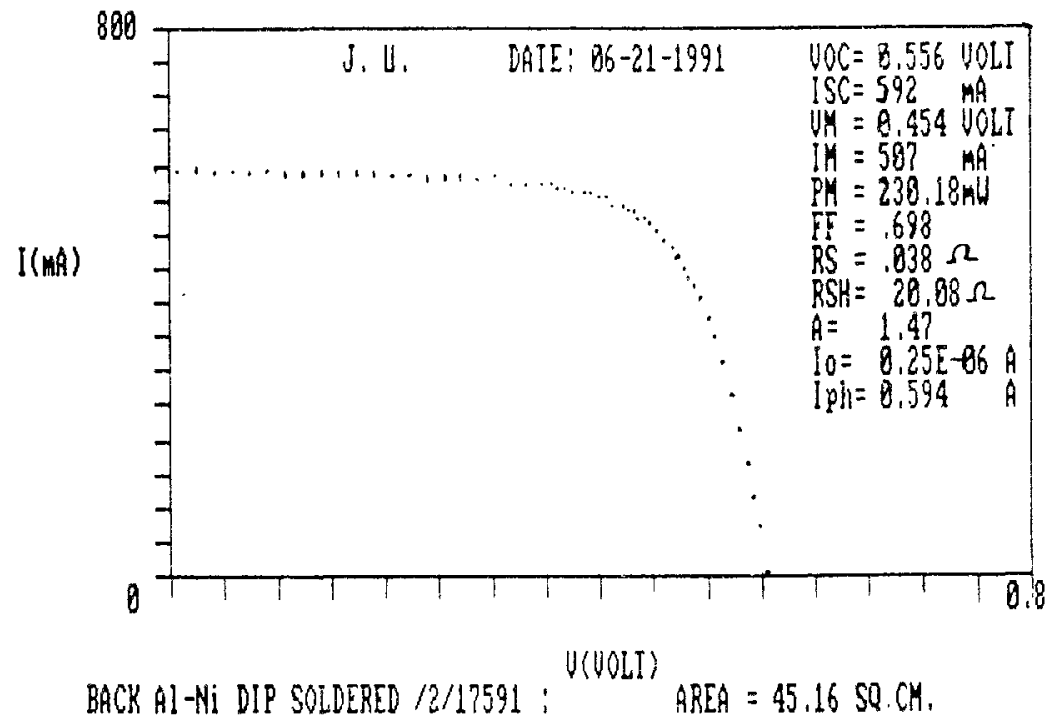

Figure 5. V-I characteristics of solar cell with computerized parameters of solar cell measured at a intensity of $40 \mathrm{~mW} / \mathrm{cm}^{2}$.

open air anneal for silicide formation. XPS was used to examine the stoichiometry and the nature of bonding of the nickel silicide layer.

\section{Results}

Figure 5 shows the typical $V-I$ characteristics of the solar cells having $\mathrm{Ni}$-silicide front contact with calculated values of open circuit voltage $V_{\mathrm{OC}}$ of $556 \mathrm{mV}$, short circuit current $I_{\mathrm{SC}}$ of $592 \mathrm{~mA}$, fill factor FF of 0.698 , series resistance $R_{\mathrm{S}}$ of $0.038 \mathrm{ohm}$, shunt resistance $R_{\mathrm{SH}}$ of $20.08 \mathrm{ohm}$, diode ideality factor $A$ of 1.47 , reverse saturation diode current $I_{0}$ of $0.25 \mu \mathrm{A}$ and photocurrent $I_{\mathrm{ph}}$ of $594 \mathrm{~mA}$ at an illumination intensity of $40 \mathrm{~mW} / \mathrm{cm}^{2}$. The efficiency of solar cell is about $13 \%$.

Figures $6 \mathrm{a}$ and $\mathrm{b}$ show the expanded runs of the strongest XPS core lines $-\mathrm{Ni} 2 p$ doublet and $\mathrm{Si} 2 p$ respectively. The Ni $2 p_{3 / 2}$ line in figure $6 \mathrm{a}$ is shown at $852.6 \mathrm{eV}$.

The nickel silicide layer composition was determined from the intensities of the two strongest XPS lines $-\mathrm{Ni} 2 p_{3 / 2}$ and $\mathrm{Si} 2 p$. In the case of $\mathrm{Ni} 2 p_{3 / 2}$, the intensity of the small satellite line at $5 \cdot 2 \mathrm{eV}$ higher binding energy from the $\mathrm{Ni} 2 p_{3 / 2}$ peak was also taken into account. The intensities were calculated by fitting Gaussian line shapes to the recorded lines as shown in figure 6. Table 1 lists the Gaussian lineshape parameters and the relative atomic concentrations calculated from the Gaussian parameters. The composition of the nickel silicide layer was $\mathrm{Ni}_{0.5} \mathrm{Si}_{0.5}(50$ at. $\% \mathrm{Ni}$ and 50 at. \% $\mathrm{Si}$ ) indicating the formation of $\mathrm{NiSi}$.

\section{Conclusions}

About $13 \%$ efficient solar cells could be fabricated by electroless nickel metallization directly on front-textured $n^{+}$silicon surface and back $p^{+}$aluminium surface. XPS analysis reveals that NiSi is formed on the front surface even after a short heat- 

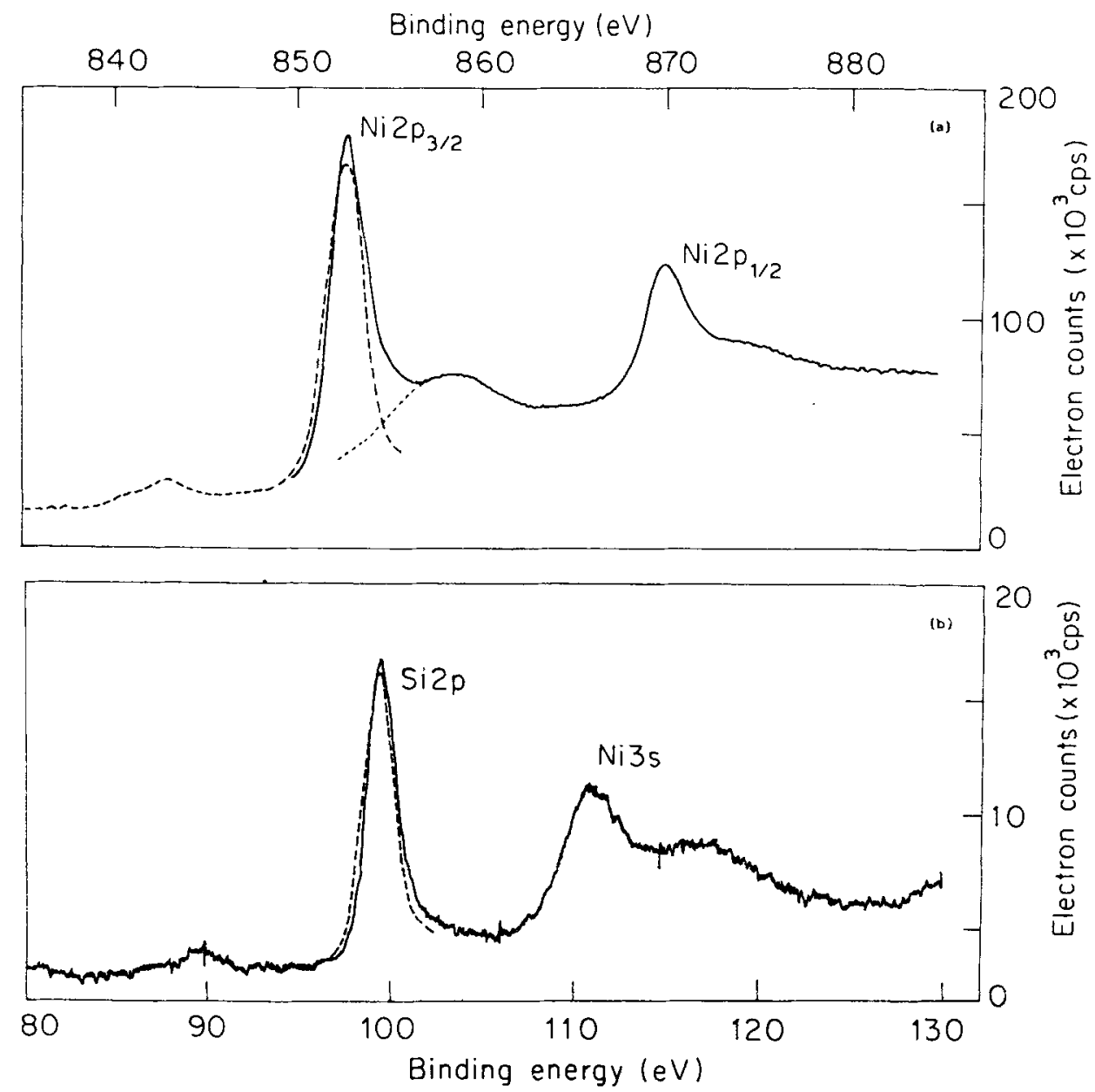

Figure 6. Expanded runs of the strongest XPS core lines. a. Ni2p doublet and b. Si $2 p$.

Table 1. Composition of nickel silicide film.

\begin{tabular}{|c|c|c|c|c|c|}
\hline $\begin{array}{l}\text { XPS } \\
\text { line }\end{array}$ & $\begin{array}{l}\text { Amplitude } \\
\left(A_{i}: \mathrm{KCPS}\right)\end{array}$ & $\begin{array}{l}\text { FWHM } \\
{\left[\Gamma_{i} ; \mathrm{eV}\right]}\end{array}$ & $\begin{array}{c}\text { Intensity } \\
\left(I_{i} ; \text { Kcps-eV }\right)\end{array}$ & $\begin{array}{l}\text { ASF } \\
\text { (si) }\end{array}$ & $\begin{array}{c}\text { Relative atomic } \\
\text { concentration }\left(C_{i}\right)\end{array}$ \\
\hline $\begin{array}{cl}\mathrm{Ni} 2 p_{3 / 2} & \left(E_{B 0}=852.6 \mathrm{eV}\right) \\
& \text { Main line } \\
& \text { Satellite }\end{array}$ & $135 \cdot 2$ & $2 \cdot 4$ & $324 \cdot 5$ & $3 \cdot 7$ & 0.49 \\
\hline$E_{B 0}=857.8 \mathrm{eV}$ & $31 \cdot 2$ & $6 \cdot 3$ & $196 \cdot 6$ & & \\
\hline $\mathrm{Si} 2 p E_{B 0}=99 \cdot 2 \mathrm{eV}$ & $12 \cdot 3$ & $2 \cdot 0$ & $24 \cdot 6$ & 0.17 & 0.51 \\
\hline
\end{tabular}

(a) Amplitude is measured in electron counts per second ( $\mathrm{CpS})$;

(b) $\Gamma_{i}=2(\ln 2 / b)^{1 / 2}$, where the gaussian lineshape function is $y_{i}=A_{i} \exp \left[-b\left(E_{B}-E_{B 0}\right)^{2}\right]$; where $E_{B}$ is the binding energy and $E_{B O}$ is the peak position;

(c) The atomic sensitivity factors (ASF) were taken from Grenon et al (1981) and

(d) $C_{i}$ 's were estimated using the equation:

$$
C_{i}=\frac{I_{i} / S_{i}}{\sum_{j} I_{j} / S_{j}} ; \quad i, j=N_{i}, S_{i},
$$


treatment for $5 \mathrm{~min}$ at $275^{\circ} \mathrm{C}$. This is very interesting since $\mathrm{NiSi}$ is usually reported to be formed only at temperatures between $325^{\circ} \mathrm{C}$ and $425^{\circ} \mathrm{C}$ (Tu et al 1975; Schmid et al 1983). However, John et al (1987) reported that the formation of $\mathrm{NiSi}$ is favoured when $\mathrm{Si}$ is in excess. Thus it appears that texturization of (100) Si surface exposed the (111) $\mathrm{Si}$ surface which is Si-rich, augmenting the formation of $\mathrm{NiSi}$. Thus the presence of NiSi may eventually lead to a very good, low-resistance and durable contact on silicon solar cells. In fact, electroless nickel metallization is now being used in high efficiency laser-grooved silicon solar cells.

\section{Acknowledgement}

The authors wish to convey their thanks to the Department of Science and Technology, Govt. of West Bengal for sponsoring the work. Thanks are also due to Dr S K Lahiri, CGCRI and Prof. M K Mukherjee, Jadavpur University for many helpful discussions.

\section{References}

Anderson J R and Petersen R C 1980 Proc. IEEE Photovoltaic sp. conf., p. 948

Bhattacharya G and Saha H 1986 Proc. IEE 133289

Cocorullo G, Prezioso G and Zarcone M 1984 Solar Cells 1119

Coleman M G, Bailey W L and Pryor R A 1976 Proc. 12th IEEE Photovoltaic specialist conf., p. 313

Coleman M G, Pryor R A and Sparks T G 1978 Proc. 13th IEEE Photovoltaic sp. conf., p. 597

Gangopadhyay U, Sinha K and Saha H 1987 Indian J. Phys. A61 266

Green M A and Cambbell P 1987 Proc. IEEE Photovoltaic specialist conf., p. 912

Grenon L A, Sakiotis N G and Coleman M G 1981 Proc. IEEE Photovoltaic specialist conf., p. 522

John P K, Rastogi A C, Tong B Y, Wu X W and Wong S K 1987 Can. J. Phys. 651037

Lee D B 1969 J. Appl. Phys. 404569

Lue J T, Changliu Y and Shen W J 1981 Appl. Phys. Lett. 38372

Pereyra I and Andrade A M 1984 Solar Cells 12285

Rastogi A C, John P K and Tong B Y 1988 Phys. Rev. B37 8308

Schmid P E, Ho P S, Foll H and Tan T Y 1983 Phys. Rev. B28 4593

Scott M T and Stella P 1976 Proc. 12th IEEE Photovoltaic specialist conf., p. 600

Singh R N, Skelly D W and Brown D M 1986 J. Electrochem. Soc. 1332390

Sopori B L and Pryor R A 1983 Application to solar cell, Proc. IEEE, p. 466; Solar Cells 8249

Sze S M 1981 Physics of semiconductor devices, (New Delhi: Wiley Eastern)

Tu K N 1975 Appl. Phys. Lett. 27221

Tu K N, Chu W K and Mayer J W 1975 Thin Salid Films 25403

Walser R M and Bene R W 1976 Appl. Phys. Lett. 28624 